\title{
SEAL EXPLOITATION
}

[Review by David Sergeant of Nigel Bonner's Seals and man: a study of interactions. Seattle and London, University of Washington Press, 1982, xii, 170 p, illus. Softcover].

Earlier books on seals aimed at a wide readership have dealt with systematics and zoogeography, or with anatomy, physiology and behaviour. Bonner here updates the systematics and zoogeography of seals with text and maps, and summarizes their evolution, adaptations and social structure as necessary groundwork, but thereafter devotes himself to the history of exploitation of seals by man, the recent state of management of a variety of species, and a number of other interactions between man and seals, especially over fisheries. The book is therefore unique. It results from a series of lectures, which have not apparently been much expanded, and is eclectic rather than comprehensive, reflecting the author's own broad experiences. Thus, the Antarctic seals are dealt with at length, as are the sub-Antarctic Fur Seals and the Southern Elephant Seal. The problems of control of the British Grey Seal population receive an up-to-date analysis. Less fully discussed are the South African Fur Seal fishery (third in importance in the world after the North Pacific Fur Seal and the North Atlantic Harp Seal fisheries), the Arctic seals and walrus, and the subtropical Northern Hemisphere Monk Seals.

The author was unlucky in that this book seems to have been completed just before the publication in 1981 of the results of an important symposium held in 1978 on 'The dynamics of large mammal populations' (Fowler and Smith 1981) which gives the specialist important new reviews, no less than three on the management of the Pribilof Island Fur Seals and one on north-west Atlantic Harp Seals.

The further perspective given by these papers allows, I think, one generalization that Bonner did not achieve, if one compares the Pribilof Fur Seal hunt with that for Harp Seals in the north-west Atlantic. The Pribilof hunt had reached its peaks by the 1950 s, and declined thereafter, in spite of great attempts to maintain production. As the result of unexplained, increased mortalities of pups at this time, it was decided to cull adult females in addition to the main harvest of subadult males, to try and stabilize and maximize recruitment. Although the rate of juvenile survival increased as planned, it was more than offset by the loss in potential births. A possible alternative experiment of culling moulted pups was never undertaken, although the South African Fur Seal hunt is maintained by killing moulted pups with some adult males. The Harp Seal hunts by Canada in the north-west Atlantic and the Soviet Union in the White Sea, take as much as 75-85 per cent of the catch as young animals, and with relatively constant quotas the populations steadily increase; this bespeaks a relatively constant juvenile mortality. Harp Seals in the 1980s, therefore, are in much the same position as were the Pribilof Fur Seals before the peak of the 1950s. If the hunt for Harp Seals continues, we may expect biological complications to begin in the near future when peak populations are reached.

It now seems, however, that emotional considerations will overcome rational ones. The public presses for an end to sealing, irrespective of their necessity to northern inhabitants; at the very least, this pressure lowers the value of seal pelts. With the Harp Seals, a compromise might be reached to exclude the catch of whitecoats, replacing them with the one-month-old, moulted beaters. These can be killed humanely by clubbing or shooting at short range because of their tameness; their pelts are of good quality, and their meat is suitable as human food.

My only other comment of substance on Bonner's book is that I would like to have seen more on the history of sealing, and especially, on the utilization of seal products. The Canton trade that stimulated the late 18th and early 19 th century fur seal hunting was indeed based on furs. These were worn by rich Mandarins and their wives during the cold north Chinese winters as a lining to their clothing, as one can see in paintings of the time. They remind one of the furs worn by late medieval European gentry, as pictured by Memling and Holbein. The Chinese knew, by 1795, how to remove the guard hairs from the fine underfur of fur seal pelts (Staunton 1797). Minor comments are that the Grey Seals in the Palaeolithic bone carving (Fig 2-1), not the salmon, were swimming on their backs, and that the references, though not the text, contain errors which more thorough checking would have removed.

The author's style, as we have been led to expect from his earlier writings, is clear and straightforward. I judge this a fine review for students and non-specialists curious to learn more about

* Fisheries and Oceans Canada, Arctic Biological Station, 555 Blvd St Pierre, Ste Anne de Bellevue, Québec, Canada, H9X $3 R 4$. 
seals and how they have fared in our modern world. For the specialist, it is a mine of information which will tempt him of her, as it has done for me, to dig more deeply.

\section{References}

FowLER, C. W. and SMITH. T. G. eds. 1981. The dynamics of large mammal populations. New York, Wiley and Sons. STAUNTON, G. 1797. An authentic account of an embassy from the King of Great Britain to the Emperor of China [etc]. London, W. Bulmer.

\section{In Brief}

\section{SIBERIAN ORIGINS OF ALASKAN ATMOSPHERIC HAZE}

Industrial haze over Alaska on cold winter days has been traced by spectrometry to ore-smelting operations in northern Eurasia. Working from the Geophysical Institute of the University of Alaska, Fairbanks, Dr Glenn E. Shaw has analysed air samples taken during three periods of persistent haze. During mid to late February, late March and early April 1982, these spells occurred when anticyclones over eastern Siberia, coupled with troughs of low pressure over north central Eurasia, were directing streams of contaminated air across the Arctic basin toward Alaska. Heavy metal ions and sulphur in the aerosol that caused the haze suggested a likely origin in the smoke plumes of Noril'sk, an important mining and smelting complex on the southern Taymyr Peninsula [Poluostrov Taymyr], over $4000 \mathrm{~km}$ from Fairbanks. (Source: Nalure, 299 (5886), 28 October 1982.)

\section{RETURN OF THE TRANSGLOBE EXPEDITION}

After a record-breaking journey of 45 days by snowmobile from the Canadian coast to the North Pole, a run of $480 \mathrm{~km}$ southward across drifting ice floes in the direction of Svalbard, and a 99-day period of waiting near the southern edge of the pack ice, Sir Ranulph Fiennes and Charles Burton made a final rendezvous with MV Benjamin Bowring, their expedition ship, on 3 August 1982. Their return to Britain three weeks later marked the end of a journey of over $80000 \mathrm{~km}$ that had taken them, in just less than three years, twice through the tropics and across both polar regions. The Antarctic section of the expedition was reported in 1981 in Vol 20 of Polar Record (129: 572-75). An account of the northern polar section will appear in a later issue.

\section{FILM ON THE LIFE OF SIR DOUGLAS MAWSON}

A 55-minure documentary film on the life of Sir Douglas Mawson has recently been produced by the Australian Broadcasting Corporation's television natural history unit, in association with the Australian Antarctic Division. 'Douglas Mawson-the survivor' forms part of the Commonwealth's celebrations to mark the centenary of Mawson's birth. Though born in Bradford, England in 1882, Mawson lived most of his life in Australia. The film is centred on a reconstruction of the 1913 sledging journey of which Mawson was the only survivor. It includes material shot on location at Commonwealth Bay, Antarctica, and interviews with members of the explorer's family, former students and expedition colleagues. (Source: ANARE News, August 1982.)

\section{RUBBER PIPELINE FOR THE BEAUFORT SEA}

A buoyant pipeline of heavy rubber, built from $11.6 \mathrm{~m}$ sections manufactured in the Netherlands, will be used in dredging silt during the construction of artificial islands for drill rigs in the Beaufort Sea. Ninety-six sections of the flexible pipeline, each over a metre in internal diameter, were recently transported across Canada by rail from Halifax to Hay River on the Great Slave Lake, and thence by barge train down the MacKenzie River to McKinley Bay. The completed pipe will form the delivery end of the dredging operation, in which silt is lifted from the sea bed to create platforms for the accommodation of drill rigs and their crews. (Source: Canada Weekly 10 (36), 28 September 1982.) 